\title{
Metodes in die Christelike etiek
}

\author{
R M Naudé \\ Sentrum vir Diens en Teologie, Pretoria
}

\begin{abstract}
Methods in Christian ethics

The basic question in Christian ethics is not primarily 'What should I do?' The basic question is rather 'How should I know what I should do?' This article describes two methods, namely, the inductive and the deductive methods as existing answers to the 'how' question. Due to criticism on these methods a symbiotic method is proposed as an alternative answer. The theological point of departure is that God and man exist symbiotic, that is co-existent to each other. The conclusion reached from this point of departure, is that the relationship between God and man, Scripture and the situation is of reflective nature and should therefore be accepted as being part of the method used in Christian ethics.
\end{abstract}

\section{INLEIDEND}

Die basiese vraag wat tradisioneel in die Christelike etiek gevra word, is 'Wat moet ek doen?' Met hierdie vraag word die doel en inhoud van die etiek aan die orde gestel. Filosofies-eties word die vraag onder andere op die volgende wyses beantwoord:

- met dit wat genot meebring (eudaemonisme);

- dit wat die grootste goed vir die grootste aantal meebring (utilitarisme);

- dit wat plesier, genot of vreugde gee (hedonisme).

Wanneer 'n mens hierdie vraag wil beantwoord met 'n beroep op die Skrif, is dié vraag nie voldoende nie. Voordat die vraag 'Wat moet ek doen' beantwoord kan 
word, moet eers gevra word na die metode wat gebruik word om 'n antwoord te verkry. Die vraag wat dus gevra moet word is 'Watter metode moet ek gebruik om te weet wat ek moet doen?' Hierdie vraag het akuut geword vanweë verskillende beskouings wat gehandhaaf word oor wat die Woord van God vir mense vandag beteken. Hierdie beskouings word begrond deur 'n Skrifbeskouing en werklikheidsverstaan wat hoofsaaklik uiteenval in (wat genoem word) of vertikalisme en horisontalisme of transendentalisme en immanentisme of objektivisme en subjektivisme. 'n Tweede aspek hiervan is die verhouding tussen teorie en praktyk, skrif en situasie en dogmatiek en etiek. Die meeste beskouings maak 'n keuse in terme van of...df. Die vraag wat beantwoord moet word, is of dit die enigste keusemoontlikheid is. Moet die moontlikheid van 'n sintetiese en...en nie dalk oorweeg word nie?

Die terme wat gebruik word om die keusemoontlikhede ten opsigte van metode aan die orde te stel, is 'induktief' en 'deduktief'. Die induktiewe metode wil op grond van ervaring die wil van God vind vir 'n etiese lewe. Die deduktiewe metode wil aan die hand van prinsiepe of norme of beginsels algemeen rigtinggewende antwoorde bied as verwoording van die wil van God vir die etiese lewe. Die uitoefening van ' $n$ keuse in hierdie verband beoog om uit te mond in 'n voorgestelde metode vir die Christelike etiek.

\section{DIE INDUKTIEWE METODE}

Die induktiewe metode word geillustreer aan die hand van die etiese teologie, die kontekstuele teologie en die situasie-etiek.

\subsection{Die etiese teologie}

Die metode van die etiese teologie word weergegee volgens die denke van Chantepie de la Saussaye. Die sistematisering van sy denke, waarvan hyself nie 'n voorstander was nie, maak dit duidelik dat die induktiewe metode van die etiese teologie sy wortels het in die beskouing oor openbaring. De la Saussaye (1922:15) dui aan dat God nie waarhede openbaar wat daarná beleef moet word nie. God se openbaring is meedelings van lewe wat vasgelê word in stellings. Hy beskou lewe as die openbaring van die ewige in die tyd. Dit het vaste wortels in die verlede van die historiese openbaring van God. Onder leiding van die Heilige Gees bied openbaring egter steeds nuwe vorme, insigte en take aan die Christelike etiek (De la Saussaye 1922: 16). Op grond van hierdie beskouing van openbaring is De la Saussaye (1922:15) van mening dat die dogmatiek nie eties nie, maar dat die etiek dogmaties behandel moet word. Dit beteken dat die Christelike moraal nie geskep word in die studeer- 
kamer van die gelowige geleerde nee, maar wel gevorm word deur die lewe van 'n geloofsgemeenskap (De la Saussaye 1922:17).

Aansluitend hierby word gestel dat die ewige buite en bo enige tyd staan. Op grond hiervan verwerp De la Saussaye die beskrywing van die Christelike moraal as 'objektief' wat aan elke mens self oorlaat hoeveel hiervan tot persoonlike eiendom word. Moraal as 'objektief' let nie op die verskil in tyd nie en skep 'n lewensleer wat dieselfde is as eeue gelede. As egter aanvaar word dat die ewige lewe in die tyd geopenbaar word, dan moet die Christen sy roeping aanvaar in die beroeringe van elke dag (De la Saussaye 1922:19). Met hierdie gedagte begrond De la Saussaye nie alleen sy siening van die taak van die Christelike etiek nie, maar ook die gebruik van bronne vir die kennis van die Christelik-sedelike. Hy ontwerp geen teoretiese moraal uit denknoodwendighede of uit een of ander stelsel nie. Hy is pragmaties. Feitlike gegewens is nodig: Hierdie gegewens self vorm en wysig dikwels die sedelike insigte (De la Saussaye 1922:20).

In aansluiting by sy pragmatiese inslag sien hy ook die geskiedenis as ' $n$ kenbron van die etiese. Sy gedagte is dat die wese van die Christelik-sedelike lewe eers in die ontwikkeling of ontplooiing bekend word. Eers in die loop van eeue toon die Christelike lewe wat dit vermag en kan doen in die wêreld. Die geskiedenis as kenbron vir die etiese beteken egter nie dat die verlede reglynig voorskriftelik vir die hede is nie. Die huidige situasies is totaal verskillend van byvoorbeeld dié van die vroeë kerk (De la Saussaye 1922:27). Daarom sien De la Saussaye dit as 'n dwaling om te reken dat die water by die bron die suiwerste is en dat dit daarom noodsaak. lik is om die apostoliese Christendom te herstel. Die geskiedenis is wel van belang omdat die Christelike lewe nie geskei kan word van die persoon van Jesus nie. Hy is die sedelike grondkrag van die Christelike lewe (De la Saussaye 1922:28).

$\mathrm{Na}$ aanleiding hiervan stel De la Saussaye dat, benewens die feitlike gegewens en die geskiedenis, ook die Skrif die kenbron van die etiese is. Hy sien die Skrif as die oorkonde van die openbaring. In die Skrif word geen samehangende openbaring gevind nie, maar uiteenlopende toestande, denkbeelde en gevoelens tree die leser tegemoet. Die eenheid in hierdie verskeidenheid is nie dat alles God se Woord is nie - dit lê daarin dat die Skrif die veelstemmige ego is wat deur die geloof op God se werk gegee word. Die Skrif as ego van die geloof wil daarom nie waarhede of wette afkondig vir alle tye nie. Die waarheid is alleen te vind in Jesus Christus, wat die inhoud is van die Christelike geloof (De la Saussaye 1922:21). Daarom sê De la Saussaye (1922:23) dat die persoon van Jesus Christus, eerder as die Christelike dogma, die kenbron is van die etiese. Op grond van hierdie beskouing kan sy induktiewe metode in 'n paar stellings saamgevat word: 
- Die lewe is die openbaring van die ewige in die tyd (De la Saussaye 1922:16).

* Dogma is die neerslag van die lewe (De la Saussaye 1922:15).

* Geloof is lewe (De la Saussaye 1922:5).

* Teorie volg ná die praktyk (De la Saussaye 1922:18).

\subsection{Die kontekstuele teologie}

Die term 'kontekstuele teologie' word gebruik met inbegrip van die etiek van bevryding, etiek van die Marxisme en Swart Teologie, op grond van die ooreenkoms in metode (Boesak 1984:61, 65; Hebblethwaite 1982:92).

Die etiek van die Marxisme steun basies op die siening van Karl Marx oor die geskiedenis. Marx postuleer dat die lewe nie bepaal word deur die bewussyn nie, maar die bewussyn deur die lewe (Norman 1983:180). Die gedagte is dus dat die mens uitsluitlik die produk van sy omstandighede is. Die metode om van die mens 'n beter mens te maak, is om die omstandighede te verander. Die moraliteit wat aan hierdie metode gekoppel word, is dat dit wat goed is alleen dit is wat die vernietiging van die onderdrukkende status quo bevorder en wat die werkersklas verenig om 'n nuwe kommunistiese gemeenskap te bou. Lenin aanvaar dieselfde moraliteit met die spreuk 'Die doel heilig die middele'. Die enigste vraag wat vir hom geldig is in verband met die middele wat gebruik kan word in die politieke stryd, is of dit sal lei tot die sukses van die stryd (Norman 1983:193). Hiermee is die insig gegee dat vanuit die konteks vormgewend en normgewend te werk gegaan kan word om 'n bepaalde doel te bereik. Die norm vir en die vorming van aksies word gevind aan die hand van 'n sosiale analise.

Die Kairosdokument (1987:34) se kritiek teen die teologie van die kerk omvat primêr die beswaar dat die teologie in die verlede nie 'n sosiale analise toegepas het nie. Hierteenoor word die profetiese teologie gestel wat verband hou met 'n 'people's theology'. Hierdie teologie vind sy oorsprong in die ervaring van onderdrukking, tirannie, konflik en stryd: 'It is with this in mind that we must begin to search the scriptures' (Kairos Document 1987:9, 17).

Hieruit kan afgelei word dat die kontekstuele teologie hom besig hou met die beantwoording van die vrae wat gevra word binne 'n bepaalde sosiale konteks. Die konteks word gedefinioer as die politieke konteks van onderdrukking en van die stryd om bevryding (Nolan \& Broderick 1987:18). Op hierdie wyse word ortopraksie gestel teenoor ortodoksie.

Tradisioneel word geredeneer vanaf die regte geloof na die regte lewe, van ortodoksie na ortopraksie. Die induktiewe metode beteken daarenteen dat die praktyk die geloof voorafgaan. Alhoewel Nolan en Broderick (1987:24) dit as onwaar af- 
wys, blyk dit uit uitsprake van ander bevrydingsteoloë dat hierdie gedagte diep gewortel is in die metode wat die kontekstuele teologie gebruik. Assmann (1975:104) beskryf die situasie as die teks van die kontekstuele teologie. Mogoba (1975:2) beskryf die taak van die kerk onder andere as 'response-ability' in die sin dat die kerk 'n 'doing church' word op grond van wat hy by die 'people' gehoor het. Cone (1975: $205,209)$ sien swart ervaring as die grond vir die etiese optrede. 'n Voorbeeld hiervan is sy interpretasie van diefstal: Hy beoordeel diefstal as verkeerd wanneer van ' $n$ mede-slaaf geneem word. Hy ag dit egter nie as diefstal wanneer van 'n witman geneem word nie. Etiese norme word volgens hom gerig op oorlewing. Hy glo daarom nie dat swartmense moreel gebind word deur onderdrukkers wat hulle verneder het tot slawerny nie. Hierdie klem wat op ortopraksie geplaas word, hou verband met ' $n$ bepaalde interpretasie van wat openbaring beteken.

Enrique Düssel $(1988: 222,229)$ maak die opmerking dat in die daad van die hoor van die stem van die ander (ex auditu) die openbaring van God beleef word: 'To hear the voice of the poor here and now is the sine qua non of the actuality of God's revelation... We take our place amongst the poor in order to hear revelation. The poor are Christ, here and now and constitute the route to a discovery of and discourse upon God.'

Gutierrez (1974:15) beskryf kontekstualisering as die sien waar God aan die werk is. Die Institute for Contextual Theology (ICT s a:10) stel dit as 'n kenmerk van kontekstuele teologie dat daar altyd eers gekyk word na wat Christene in die praktyk doen en wat die 'people' oor God sê. Dit word gestel teenoor 'n teoretiese verklaring van die kerk oor wat dit behoort te wees en teenoor abstrakte denke oor wat Christene behoort te doen. Kontekstuele teologie word beskryf as 'n metode wat prakties van aard is, want dit begin en eindig met die praktyk van die Christendom. 'n Voorbeeld hiervan is die vraag van ' $n$ groep mense oor wie God is. Die groepe het afwysend gestaan teenoor die beskouing dat God veraf is en die beskouing dat God wonders doen, terwyl die mens passief is: 'The group felt instinctively that God must be the great liberator and defender of the poor. They began to search the scriptures again with this question in mind.'

Die gevolgtrekking wat gemaak word na aanleiding van instinktiewe geloof, is dat God die mens dien en dat Hy in en deur 'ons' handel (ICT s a:8).

Hiermee is die verhouding tussen openbaring en die 'people' aan die orde gestel: Dit word beskryf aan die hand van die sensus fidei. Geloof word omskryf as ervaring. Die betekenis hiervan is dat geloof nie gegrond word op prinsiepe en leerstellings nie, maar eerder op ervaring van die 'tekens van die tye' wat reeds gedefinieer is as onderdrukking. Geloof, los van die leerstellige, word 'n instinktiewe geloof (Nolan \& Broderick 1987:22, 23). Die gedagte is dus dat die mens oor die ver- 
moë beskik om te weet wat reg of verkeerd is. Die beslissing van wat reg of verkeerd is, word gelyk gestel aan 'n beslissing van God asof dit God self is wat dit openbaar. Die 'people' is, in terme van die sensus fidei, die openbaring van God.

Hierdie verstaan van die betekenis van openbaring vorm die grondslag van die 'people's theology'. Die gedagte is dat die 'people' die eintlike teoloë is. Die wetenskaplike teoloë of studeerkamerteoloë het egter tog 'n rol te speel: Hulle hulp word benodig om te verseker dat die regte vrae deur die 'people' aan die situasie gevra word (Mkhatswa 1990:6). Die vraagstelling bepaal tot 'n groot mate die aard van die antwoorde wat gegee sal word, wat dan as openbaring van God beskryf word. As dít in gedagte gehou word, speel die studeerkamerteoloog 'n bepalende rol in die 'people's theology'. Die openbaring van God word verkry deur middel van 'n groepmetode wat genoem word See-Judge-Act of Action-Reflection-Action. Aan die hand hiervan ontwikkel 'n groep sy eie teorie en praktyk (Nolan \& Broderick 1987:27). Die resultaat van die groepmetode is dat die gemeenskap verdeel word in onderdrukkers en onderdruktes. 'n Onversoenbaarheid met die onderdrukkers word geskep deurdat 'n keuse as onafwendbaar gestel word. Omdat die paradigma 'God is aan die kant van die onderdrukte' verkondig word, word die Christen opgeroep om hom te skaar aan die kant van die onderdrukte (Kairos Document 1987:28). Die bedoeling van die kontekstuele teologie is om 'basiese belydenisgemeenskappe' te vorm binne elke godsdienstige tradisie en kerkverband om die massa te 'bekeer' tot die beëindiging van die onregverdige status quo. Die uiteindelike doelwit is om die 'People's Church' te vorm in onderskeid van die tradisionele kerke (Buro vir Suidelike Afrika 1985:4). Op hierdie wyse mond die induktiewe metode van die kontekstuele teologie uit in 'n bepaalde vorm van kerkwees en in 'n bepaalde lewenstyl. Die aard hiervan word nie verder bespreek nie.

\subsection{Situasie-etiek}

Joseph Fletscher (1966:11) wou met situasie-etiek nie 'n etiese sisteem skep wat mense hulle vryheid ontneem nie, maar hy wou 'n metode van situasionele of kontekstuele besluitneming aanbied. Die wortels van die situasie-etiek lê in die klassieke tradisie van die Westerse Christelike moraal, maar is vry van die odium theologicum. Situasie-etiek is nie Katoliek, Protestants, Ortodoks of Humanisties nie; dit is persoonlik en kontekstueel. Dit is situasie-sensitiewe besluitneming en kan ideologies, teologies of nie-teologies wees. Omdat Fletscher $(1966: 13,14)$ in die eerste plek 'n metode aanbied, is hy beskuldig daarvan dat sy etiek nie Christelik is nie. Tog vul hy hierdie metode met Christelik norme. Hy stel in wese 'n Christelike situasie-etiek voor met Christus as inhoud van die etiek (Fletscher 1966:157). 
Fletscher plaas situasionisme tussen ekstreme wettisisme en antinomianisme. Hy ontken hiermee, aan die een kant, dat daar 'n wet vir alles is, en aan die ander kant dat daar geen wet vir enigiets bestaan nie. Hy wil wettisisme vermy, omdat hy van mening is dat ' $n$ lewe volgens wette 'n sensitiwiteit vir die seerkry van die lewe verloor. Hy noem wettisisme ' $n$ sadistiese gebruik van die wet wat seermaak in plaas van om te help. Wettisisme handhaaf die spreuk fiat iustitia ruat cael im - laat geregtigheid geskied, al val die hemel (Fletscher 1966:19, 20).

In sy reaksie hierop maak Fletscher hom egter nie skuldig aan antinomianisme nie. Antinomianisme is die benadering waar besluite geneem word sonder dat enige norm of prinsiep in ag geneem word. In elke eksistensiële moment of unieke situasie word gesteun op die situasie self - daar en dan - om die etiese antwoord te vind (Fletscher 1966:22, 23).

Fletscher aanvaar met situasie-etiek wel die rede as instrument vir morele beoordeling en verwerp terselfdertyd dat die goeie 'n gegewenheid is in die aard van dinge. Hy aanvaar ook openbaring as die kenbron van die etiese norm, maar verwerp alle geopenbaarde norme of wette behalwe om God en die naaste lief te hê. Alleen die imperatief tot liefde is kategories goed (Fletscher 1966:26). Hiermee dui hy aan dat daar in die situasie-etiek 'n element van berekening sowel as 'n element van absoluutheid is. Die verpligting is relatief tot die situasie, maar die verpligting in die situasie is absoluut. So handhauf situasie-etiek 'n absolute norm en 'n bere-kende metode. Die situasionele faktore is egter primêr, sodat die omstandighede die reëls en prinsiepe kan verander. Situasie-etiek is saak-gefokus en konkreet. Dit wil op hierdie wyse Christelike imperatiewe prakties maak (Fletscher 1966:27, 29). Daarom geld vier prinsiepe in die situasie-etiek:

- Pragmatisme: 'n Pragmatis is gekant teen abstraksie, vasgestelde prinsiepe en geslote sisteme. 'n Pragmatis bevorder eerder konkreetheid, genoegsaamheid, feite en aksie. Situasie-etiek wil in dié sin pragmaties wees (Fletscher 1966:40).

- Relativisme: Die strategie van die situasie-etiek is pragmaties maar sy taktiek is relativisties. 'n Situasionis vermy woorde soos nooit, perfek, altyd, kompleet en absoluut. Tog erken Fletscher dat die voorwaarde vir relatiwiteit juis die absolute of die norm is. Liefde relativeer die absolute, maar verabsoluteer nie die relatiewe nie. Dit beteken dat norm dieselfde is in sy 'wie' en 'wat', maar veranderbaar is in sy 'hoe' (Fletscher 1966:44, 45).

- Positivisme: Dit is denke gesteun deur geloof. Dit stel geloof in God bo alles en beredeneer wat gehoorsaamheid beteken in bepaalde situasies (Fletscher 1966: 47). 
* Personalisme: Situasie-etiek plaas mense, eerder as dinge, in die middelpunt van besluitneming. Die wettisis vra, 'Wat sê die wet?' Die situasionis vra, 'Wie moet gehelp word?' (Fletscher 1966:49, 50).

Hierdie vier prinsiepe in die situasie-etiek maak dit duidelik dat die fokus geplaas word op 'pragma' en nie op dogma nie. In die besluitnemingsproses word nie antwoorde gevind deur voorskrifte na te slaan nie. Situasie-etiek vra ook nie, 'Wat is goed?' nie, maar eerder, 'Hoe moet goed gedoen word vir wie?' Die vraag word ook nie gevra, 'Wat is liefde?' nie, maar eerder, 'Aan wie moet liefde betoon word?' (Fletscher 1966:50, 51). Alhoewel die dogma of norm of prinsiep 'n rol speel, is die korrektheid van die daad afhanklik van die wyse waarop dit realiseer in 'n situasie (Fletscher 1966:59). In situasie-etiek kan prinsiepe oorboord gegooi word as dit in konflik is met die liefde binne 'n gegewe situasie (Fletscher 1966:33).

Fletscher stel dat die Christelike situasionis ter oorweging van 'n korrekte daad drie vrae vra: 'Wat?' (liefde), 'Waarvoor?' (ter wille van God) en 'Vir wie?' (mense, naaste). Binne die situasie word gevra, 'Wanneer, waar, hoe, watter een?' om die kairos-faktore te bepaal. Aan die hand van feite word die regte optrede bepaal. Dit noem Fletscher 'n ekologie-etiek. Ekologie as die studie van die verhouding tussen 'n organisme en sy omgewing, word gebruik om aan te dui dat situasie-etiek - soos die ekologie - die omgewing (konteks) in ag neem vir elke beslissing wat gemaak word (Fletscher 1966:142).

Situasie-etiek kan metodologies in die lig van die voorafgaande denke van Joseph Fletscher omskryf word as induktief terwyl inhoudelik die normatiewe pragmaties gehandhaaf word.

Die induktiewe metode kan verder ook geillustreer word aan die hand van die etiek van J A T Robinson, Paul Lehmann en die Prosesetiek.

\section{DIE DEDUKTIEWE METODE}

Die deduktiewe metode word aan die orde gestel aan die hand van die Protestantse Ortodoksie, die reformatoriese etiek en die etiek van Karl Barth. Die keuse hiervan bedoel om die nuanseverskille in hierdie metode aan te dui.

\subsection{Die Protestantse Ortodoksie}

Die periode vanaf die Reformasie tot en met die Aufklärung staan bekend as die konfessionele tydperk. Hierdie tydperk is gekenmerk deur die heerskappy van die Ortodoksie. In hierdie periode is die klem veral geplaas op die suiwer leer. Gevolglik het die klassieke dogmatiese sisteme op grond van die Reformasie na vore ge- 
kom. Die Ortodoksie begin teen die middel van die sestiende eeu. Die sluiting van die Kondordienformel (1577) het die reformatoriese leer binne die Lutheranisme beeindig. Die Sinode van Dordrecht (1618-1619) het binne die Gereformeerde tradisie 'n soortgelyke posisie ingeneem. ' $n$ Nuwe skolastiek het in beide van die Reformatoriese kerke begin wat vergelyk kan word met die gestrengheid van die middeleeuse skolastiek (Lohse 1974:217, 218).

Die gestrengheid van die Ortodoksie het gesentreer rondom die suiwerheid van die leer. Dit was die erns van die Ortodoksie om die regte geloof te bevorder en so God en die saak van die kerk te dien (Lohse 1974:218). Hierdie aspek van die Ortodoksie is van groot belang omdat hierdie motief verband hou met die metode wat bespeur kan word. Die oortuiging het bestaan dat as die gesag van die Woord en die Skriftuurlike dogmas nie ongeskonde bewaar word nie, die Christelike geloof in duie sou stort. In die plek van die geopenbaarde Woord van God sal die menslike rede, wil en wense seëvier (Engelbrecht 1982:30). Hierdie bewarende motief mond in genoemde tydperk uit in 'n Skrifleer en 'n inspirasieleer wat 'n kenmerk van die Ortodoksie geword het. Die Skrifleer het nie weer, soos tydens die Ortodoksie, s6 in die brandpunt gestaan nie. Tegelyk het dit egter ook indirek die latere tydperk van die Aufklärung voorberei (Lohse 1974:219).

Die Skrifleer is geformuleer in die Konkordienformel (1577; my vertaling): 'Ons glo, leer en bely dat die enigste reël en rigsnoer waarvolgens tegelyk alle leer en leraars gerig en beoordeel moet word, alleen die praktiese en apostoliese geskrifte van die Ou en Nuwe Testament is: Alle ander geskrifte word onderskik gestel aan die Heilige Skrif' (Lohse 1974:219). Met hierdie formulering is gestel dat die Skrif die Woord van God is. Die gesag van die Woord is daarom absoluut (Cauthen 1986:16, 17). Hierdie Skrifleer het gepaard gegaan met die ontwikkeling van die dogmatiese leer oor die Goddelike inspirasie van die Skrif. Die motief was om met die inspirasieleer 'n oninneembare bastion teen die Rooms-Katolieke Kerk te skep. Flacius Illyricus (1520-1575) het geleer dat nie alleen die woorde in die Skrif nie, maar ook die Hebreeuse vokale Goddelik geïnspireer is. As hierdie inspirasieleer betwyfel word, word die hele Skrif twyfelagtig. Die Heilige Gees is egter die oorsprong en uitlegger van die Skrif. Hierdie gedagte is later uitgebrei. Dit was nie alleen die woorde van die Skrif wat geinspireer is nie, maar ook die skrywers van die Skrif. Die Heilige Gees het die skrywers woordeliks laat neerskryf wat hulle ingegee is om te skryf. Die skrywers van die Skrif was uiteindelik net maar die griffel wat die Heilige Gees bedien het. Die individualiteit van die skrywers het geen rol gespeel nie (Iohse 1974:220, 221).

Hierdie Skrifleer en inspirasieleer is verdedig teen die siening van die Piëtisme. Valentin Ernst Löscher (1673-1749) was een van die laastes, maar ook die felste 
verdediger van die Ortodoksie. Die Piëtiste het kritiek gelewer teen die praktiese bruikbaarheid van die inspirasieleer van die Ortodoksie. Dit is gestel dat die kennis van die Skrif en die uiterlike aanvaarding van die gesag van die Skrif nie genoegsaam is nie. ' $n$ Mens styg hiermee nie bo 'n dooie historiese geloof uit nie. Veel eerder moes die waarheid van Skrifuitsprake aan eie lyf ervaar word. 'n Mens moet in sy eie lewe die mag van die sonde en die helpende krag van die genade beleef. Daarom word genoem dat die vraag na die inhoud van die geloof nie so belangrik is soos die selfondersoek of 'n mens werklik die evangelie glo nie. Hierteenoor het Löscher gewaarsku teen die neiging om die objek van die geloof ondergeskik te stel aan die subjektief-psigologiese gelowigheid. Hiermee het die Ortodoksie egter eensydig die formalistiese en historiese waarheid van die Skrif bewaar, teenoor die Piêtisme wat gevaar geloop het om die subjektiewe ervaring tot maatstaf van die geloofuitsprake te maak (Lohse 1974:223, 224).

Die Skrifleer en die inspirasieleer van die Ortodoksie omskryf die deduktiewe metode waarvolgens die regte geloof verstaan word in terme van 'n outoritatiewe norm. Die klem word op die regte en suiwer geloof geplaas eerder as op die praktyk. Hiermee het die Ortodoksie in bykans alle lewensfere die dinamiek van die Reformasie deur 'n starre leer vervang. Alhoewel Luther en Melanchton die grondstelling sola Scriptura ondersteun het, is dit nooit belydenismatig gefikseer nie. Die Skrifgesag was vir Luther van so aard dat die Skrif krities ondersoek kon word terwyl hy tog ook die kanoniese gesag daarvan onderskryf (Lohse 1974:219). Die Skrifleer en inspirasieleer van die Ortodoksie het prakties beteken dat die Skrif seggenskap het vir die hede as die meedeling van leerstellings wat reeds geopenbaar is en geldig is vir alle mense van alle tye op dieselfde wyse. Die gevolg hiervan is dat die leer 'n starre gegewenheid word, sodat 'n dualisme tussen leer en lewe ontstaan het. Die belydenis moes geglo word in plaas van dat geloof bely word (Berkouwer 1974: 13). Veral ten opsigte van die Gereformeerde Ortodoksie is gesê dat van die Christen verwag word om 'n blinde gehoorsaamheid te hê, 'n sacrificium intellectus, wat geloof eis sonder om vrae te vra (Berkouwer 1974:222).

Weber (1964:132) gaan so ver as om te sê dat die Ortodoksie in sy verdediging van die regte leer uit voeling geraak het met die realiteite van die menslike bestaan. Tog is dit ook waar dat die individuele teoloe van die Ortodoksie die mens in die oog gehad het. So het Hollaz (1648-1713) die ordo salutis ontvou. Dit loop daarop uit dat die sondaar, verander deur die Woord van God, 'n lewe kan voer van stryd teen die sonde, van elke dag as 'n nuwe mens, totdat die saligheid ingegaan word. Die orde is egter so trapsgewys vasgelê, dat die sisteemdenke van die Ortodoksie vertoon word (Frey 1989:83). Die piëtistiese literatuur wat ná die tydperk van die 
Ortodoksie volg, bevestig egter dat, wat die etiek van die Ortodoksie betref, die konkreetheid van die Christelike lewe ontbreek het.

In sy geheel gesien, vertoon die Ortodoksie 'n vorm van die deduktiewe metode wat nie daarin geslaag het om die mens binne sy konkrete lewensituasie genoegsaam aan te spreek nie. Met hierdie vorm van die deduktiewe metode as agtergrond, is dit noodsaaklik om terug te keer na die oortuigings van Luther en Calvyn ten einde rigtinggewende denke te vind met betrekking tot die metode vir 'n Christelike etiek.

\subsection{Die etiek van Luther}

Die metode in die teologie van Luther kan alleen tot sy reg kom as die volle spektrum van sy teologie aan die orde gestel word. Binne die bestek van hierdie artikel is dit egter nie moontlik nie. Daarom word volstaan met die aanduiding van die metode soos dit gestel word met betrekking tot twee aspekte van die teologie van Luther, naamlik persoon en werk, asook geloof en liefde.

Die vertrekpunt van die teologie van Luther en gevolglik ook van sy etiek is die geregtigheid van God wat Hy aan die mens skenk (Rom 1:16, 17). Dit bring mee dat die mens nooit in homself geregverdig is nie (Pont 1984:19). Vanuit hierdie vertrekpunt wat inderdaad die verrassende resultaat van sy eksegetiese ondersoek van die Skrif was (Schultze 1984:53), het Luther standpunt ingeneem teen die middeleeuse etiek, wat 'n geestelike lewe hoër geag het as 'n liggaamlike lewe, vanweë 'n dualistiese mensbeskouing (Frey 1989:26, 27) en teen die denke van Aristoteles. Aristoteles het geleer dat 'n mens geregverdig word deur reg te doen. Hierdie siening is gegrond in sy leer van die habitus. 'n Habitus word, soos 'n deug, alleen geskep deur die actus as 'n herhalende daad wat 'n gewoonte of lewenstyl word. Die daad verkry hiermee 'n voorrang bo die habitus. Die skolastiek het die habitus verstaan in terme van die genade. Thomas Aquinas het die genade gelokaliseer in die siel van die mens. Dit beteken dat die genade as habitus van die geregverdigde persoon, eties geaktualiseer moet word in die werke. Luther het wel die onomkeerbaarheid van persoon en werk gehandhaaf teenoor die siening van Aristoteles, maar terselfdertyd genade verstaan as iets wat nie in die mens verander word nie, maar wat die verhouding met God verander. Die wese van die mens word alleen coram Deo verander. Hy definieer die persoon nie op grond van potensiaal en aktiwiteite nie, maar alleen in verhouding met God. Die feit dat die aard van die wesensbestaan van die mens voor God deur God bepaal word, gaan die betrokkenheid van die mens in die wêrelú vooraf. In dié sin onderskei Luther tussen persoon en werk, sonder om ' $n$ waterdigte skeiding te veronderstel (Ebeling 1975:150-157). 
Die voorrang wat Luther gee aan die persoon, bo werk, word verder geillustreer en belig aan die hand van die dualisme geloof en liefde. Geloof, volgens Luther, vernietig die sonde en skep 'n regverdige en gelukkige persoon. Wanneer dit gebeur, word die Heilige Gees en liefde geskenk wat hom verheug daarin om die goeie werke blymoedig te doen. Geloof bly die dader en liefde die daad. Luther skei nie geloof en liefde nie. Hy sien dit as een lewende werklikheid. Tog handhaaf hy ten spyte van die eenheid ook die onderskeid tussen geloof en liefde. Hy verstaan geloof in terme van die regverdiging. Geloof bring 'n verandering van die persoon self. Die gelowige moet die ou mens weggooi en alleen Christus as gekruisigde en opgestane in gedagte hou. Eintlik wil Luther hiermee sê dat geloof 'n eenheid skep tussen die gelowige en Christus asof dit een persoon is, sodat 'n mens nie geskei kan word van Christus nie. So is geloof die essensie van alle goeie werke. Op dié wyse word goeie werke bevry van die doel om regverdiging te verdien. Geloof bied die vryheid om te doen wat nodig is ter wille van die naaste, soos vereis deur liefde. Geloof bly egter God se saak en liefde die mens se saak. Geloof bring liefde ongevraagd na vore (Ebeling 1975:159-170).

In 'n brief aan Pous Leo $X$ in 1520 skryf Luther oor die Christelike vryheid. Hierin ontvou sy teologie wat die primaat verleen aan die innerlike mens wat gevorm word deur geloof alleen. Vanuit hierdie geloof leef die Christen as uiterlike mens 'n morele lewe wat die naaste insluit. In die lig van die defínisie van geloof spreek hy sy bekende woorde uit: Ons moet Christusse word vir mekaar. Die goeie wat 'n gelowige van God ontvang, moet deurgegee word na ander sodat dit algemeen sal voorkom by gelowiges (Luther 1502:346-372). Hierdie deduktiewe metode in die teologie van Luther sluit egter nie die situasionele uit nie. Hy is van oortuiging dat die genade van God van die mens 'n vry mens in Christus maak, wat in nuwe lewensituasies opnuut die wil van God moet ontdek. Verbonde aan Christus moet die Christen nuwe dekaloë skep. Die Christen moet verantwoordelike situasie-etiek bedryf (Van Wyk 1986:47).

Op grond hiervan kan gesê word dat die teologie van Luther deduktief van aard opgebou is, met komponente soos antitetiese stellings, dualisme en 'n dialektiese verhouding met die situasie.

\subsection{Die etiek van Calvyn}

Die omskrywing van die metode wat Calvyn in sy teologie gevolg het, is aan die een kant 'n baie moeilike onderneming, omdat Calvyn nie 'n sistematiese werk aangebied het nie. Sy Institusie is bedoel as 'n gids en rigtingwyser om aan te toon waarvoor in die Heilige Skrif gekyk moet word om die doel te bereik waartoe die 
Heilige Skrif die gelowiges uitnooi. Aan die ander kant maak die denke van Calvyn dit maklik om sy teologie as deduktief te omskryf. Die reformatoriese leer is volgens hom Bybelse leer. Om te ondersoek of iets reg, suiwer en waar is, beteken om te ondersoek of dit Bybels is (Engelbrecht 1979:3).

Hierdie denke van Calvyn word aangedui deur die bespreking van sy teologie te beperk tot twee aspekte, naamlik die kennis van God en mens, en die herskepping. Hierdie twee temas word gekies vanweë, onder andere, die illustratiewe waarde wat dit het vir die omskrywing van die metode in die etiek van Calvyn. Albei temas onderstreep die feit dat die geloofsleer en geloofslewe by Calvyn so in mekaar vervleg is dat die lewe voortvloei uit die leer.

Calvyn sê in sy Institusie dat dit die hoogste doel van 'n gelukkige lewe is om kennis van God te hê. Daarom is hy van mening dat God die kiem van die godsdiens in die harte van mense gelê het en Homself in die bouwerk van die wêreld geopenbaar het, sodat die mens gedwing word om Hom te sien, omdat God aan almal die geleentheid wil gee om gelukkig te wees (Calvyn Institusie I, i). Hierdie kennis van God is kennis van God die skepper, Jesus Christus as verlosser, en die Heilige Gees (Calvyn Institusie I, i; VI, i; III, i:1-4). Die ware kennis van God en die ware kennis van die mens is egter onlosmaaklik met mekaar verweef. Die gevolg hiervan is dat in die lig van die kennis van God, die mens homself leer ken as 'n absoluut verdorwe mens wat geen vrye wil, geen geregtigheid en geen heiligheid besit nie. Die mens is só totaal verdorwe dat hy godsdienstig en sedelik onbekwaam is tot enige goed (Engelbrecht 1979:4, 5; Calvyn Institusie II, v:19). Vanweë die totale sondigheid van die mens, moet die mens leer om nie op eie krag staat te maak nie, maar sy sterkte in God alleen te vind (Calvyn Institusie Il, ii:19). Daarom is ootmoed (Calvyn Institusie II, ii:11) en veral selfverloëning 'n belangrike en selfs die belangrikste deel van die Christen se lewe. Calvyn bedoel hiermee dat in die plek van 'n selfsugtige lewe wat soek na skatte, eer en mag, eerder 'n lewe van gerustheid en lydsaamheid geleef moet word wat getuig van die geloof en vertroue in die voorsienigheid van God wat seën en voorspoed self sal skenk soos Hy wil (Calvyn Institusie III, vii:8-10). Die kennis van God en die kennis van die mens bring Calvyn daartoe om te stel dat die mens, onmagtig in sy sonde, diep afhanklik van God moet bestaan. Eintlik wil hy sê dat die mens se ganse bestaan daarin geleë is dat hy/sy op God gerig sal lewe. So is sy teologie gebaseer op die denke van Augustinus, wat geleer het dat die mens geskape is vir gemeenskap met God en dat dit die mens onvervuld is totdat dit verwerklik is (Encyclopedia of Religion 1987).

Die verlossing of herskepping word Christosentries benader. Christus alleen is die middelaar wat die oorspronklike skepping restoureer. Restourasie of herskepping vind plaas wanneer die persoon verenig word met Christus deur te antwoord 
met geloof op die dood en opstanding van Christus (Calvyn Institusie II, vii:2). Calvyn verbind die betekenis van die middelaarskap van Christus met die werk van die Heilige Gees. Die herskepping kan alleen die sondaar bereik deur middel van die Heilige Gees. Die Heilige Gees is die band waardeur Christus die gelowiges kragtig aan Hom verbind (Calvyn Institusie III, i:1, 2). Die gevolge hiervan vir die persoon is geloof, heiligmaking (Calvyn Institusie III, i:1,2), bekering of boetvaardigheid en wedergeboorte (Calvyn Institusie III, iii:1, 9). Hiermee word aangedui dat die vernuwing van die mens 'n belangrike element is vir die etiek van Calvyn.

Die herskepping het vanuit hierdie gesigspunt ook gevolge vir die samelewing. God het die werreld geskape om 'n vertoonvenster, 'n teater te wees vir sy glorie. Die sonde het die skepping in sy totaliteit aangetas en herskepping beteken dat die lewe en samelewing herstel moet word. Die herstel van die samelewing sien Calvyn in terme van die heerskappy van God in Jesus Christus. Outonomie word vervang met teonomie en teokrasie (Engelbrecht 1979:23, 24). Die feit dat Calvyn die soewereine God en sy eer bo alles stel, beteken vir die Christelike lewe dat die Christen in sy wandel, denke en spreke gehoorsaam sal wees aan God. Die menselewe moet in sy volle omvang voor die ordinansies van God buig (Engelbrecht 1978:277).

Alhoewel Calvyn 'n oog het vir die samelewing en die lewe van mense, is die Skrif deduktief normatief geldig vir die sondige mens wat in totale afhanklikheid voor God bestaan. As nuwe mens buig die sondaar onder teonomie en teokrasie.

\subsection{Die etiek van Karl Barth}

Die etiek van Karl Barth is ten nouste verweef met sy dogmatiek. Eintlik sê Barth (1960:888) dat dogmatiek nie anders kan as om ook etiek te wees nie. Om hierdie rede het die metode wat $B$ arth volg ten opsigte van sy etiek, sy wortels in die dogmatiek. Sy dogmatiese denke word hier slegs beperk tot sy Skrifbeskouing.

Barth se Skrifbeskouing moet verstaan word in reaksie op die modernisme en liberalisme wat die openbaring van God só verstaan het dat dit ook afgelees kon word uit die skepping, wêreldgebeure, menselewe en menslike prestasies. Omdat die mens as wesenlik goed beskou is, het die menslike ervaring openbaringswaarde (Engelbrecht 1978:206). Barth (1964:38) verklaar egter dat menslike moontlikhede alleen bepaal word buite alle menslike moontlikhede om, naamlik van die handelende God. Daarom stel Barth in sy Prolegomena die tese dat die Woord van God die kriterium is vir die dogmatiek. Hiermee dui Barth (1964:11) aan dat dogmatiek alleen beoefen kan word in die erkenning van die feit dat God in Jesus Christus die waarheid is. Sy Skrifbeskouing val uiteen in drie gestaltes wat hy toeken aan die Skrif (Barth 1964:90, 97): Eerstens is die Skrif verkondigde Woord. Die Skrif maak 
die verkondigcle Woord tot verkondiging. Verkondiging as die menslike spreke oor God beteken eintlik dat dit spreke van God is waardeur Hy van Homself spreek. Op hierdie wyse is die Woord as verkondigde Woord nooit net menslike spreke nie.

Die tweede gestalte van die Woord is die geskrewe Woord. Die Woord wat verkondig word, is die Woord wat reeds gespreek is en wat reeds plaasgevind het. Daarom is die spreke oor God niks anders as die herinnering aan die openbaring van God nie (Barth 1964:101, 108). Die Skrif as kanoniese geskrif is nie 'n historiese monument nie, maar is skriftelike verkondiging wat normatief is vir die kerk. Daarom sien Barth eksegese as onontbeerlik vir die verstaan van die Skrif. Hy wys egter op die gevaar dat by wyse van inlegkunde die spreke van die kerk kan uitloop op 'n gesprek van die kerk met homself. Die herinnering van die kerk aan God se openbaring het die Skrif as objek wat 'n gebiedende en laaste woord spreek. Die Skrif is die Woord van God in soverre God deur sy Woord spreek (Barth 1964:104. 112). Op hierdie wyse laat Barth ook in die gefikseerde Woord vir God steeds God bly.

Dit word ook duidelik in die derde gestalte van die Woord as die geopenbaarde Woord. Die Skrif bly die konkrete middel van die openbaring van God. Die Skrif is nie self die openbaring nie, maar getuig van die openbaring van God. Die gesag van die Skrif is daarom nie inherent aan die Skrif self nie, maar is geleë in die getuienis oor God wat gesag verleen aan die Skrif. Skrif en openbaring kan daarom nie identies wees nie (Barth 1964:114,115). Barth verbind wel Skrif en die Woord wat vlees geword het. Die verpersoonliking yan die Woord ontwoord nie die Skrif nie, maar bevestig die Heer-wees van God ten opsigte van sy Woord wat Hy kan gebruik of nie gebruik nie, vanweë die feit dat God vrye subjek bly (Barth 1964:143).

Dit is juis as vrye subjek dat God se Woord nie in 'n lugleegte gespreek word nie, maar gespreek word tot mense. Die Woord van God is daarom 'n concretissimum waar en wanneer God tot mense spreek. Tog, ten spyte van konkreetheid, bly dit Barth se siening dat dit alleen God se Woord is wat die mens in sy bestaan kan aanspreek. Geen mensewoord kan dit vermag nie. Geen mensewoord het die laaste sê nie. Sy Woord as Heer-woord is die Woord van die skepper, versoener en verlosser (Barth 1964:145-148). Barth se verdere omskrywing van die Woord as actio en musterion vertoon dieselfde oortuiging.

Die Woord as daad van God met die mens (Barth 1964:155) en as geheimenis ten spyte van die mens (Barth 1964:173) plaas die onus op die mens om werklik God se Woord te verneem (Barth 1964:182).

Die metode in Barth se teologie kom alreeds in hierdie paar opmerkings oor sy Skrifbeskouing na vore. Sy metode word gekenmerk as deduktief, deurdat hy sy uitgangspunt vind in die beweging van God na die mens en nooit van die mens na God 
nie. Hy stel dit treffend wanneer hy sê: 'Geloof is ervaring, 'n konkrete vasstelbare tydelike handeling van hierdie mens, 'n daad van erkenning...maar ervaring maak nie van geloof geloof nie' (Barth 1964:241, 242; my vertaling).

Die konsekwensies hiervan vir sy etiek word duidelik uitgespel. Barth (1960: 886) stel dat die hoorder van die Woord van God tegelyk dader moet wees. Hiermee dui hy onder andere aan dat geen enkele aspek van die dogmatiek geïsoleerd kan dien as ' $n$ basis vir die etiek nie. Dogmatiek is in sy geheel ook etiek. Die etiese vraag is die bestaansvraag van die mens voor God. Eintlik bestaan die mens alleen onder die Woord van God wat hom toespreek. Hiermee word nie 'n outoritêre etiek geskep nie. Barth (1960:888) beklemtoon eerder dat God die mens in sy Woord wil ontmoet ten behoewe van die mens. Daarom sien hy die trinitariese belydenisse as die basis vir die etiek wat so ontvou dat die vroeëre 'jy moet' vervang word met 'jy behoort'. Sy etiek neem afskeid van die kasuïstiek en stel in die plek daarvan 'n etiek van genade waarin die vryheid van die mens 'n plek kry. Vanuit hierdie vertrekpunt beskryf Barth sy 'spesiale' etiek as 'n bemoeienis 'na onder': Dit is 'n bemoeienis van God met die handelende mens. Dit geskied op so 'n wyse dat die Woord (gebod) van God nie in die lug bly hang nie, maar die mens in sy konkrete handeling raak. Op hierdie wyse word die metode in sy etiek duidelik beskryfbaar, naamlik, 'van bo na onder' (Barth 1969:3, 4).

$\mathrm{Na}$ aanleiding van hierdie metode is dit vir Barth moontlik om te sê dat alleen deur die Woord van God die menslike bestaan teologies relevant is. Die dialektiek van die dogmatiek moet eksistensieel gerig wees, sodat die Woord van God op die menslike bestaan gerig word (Barth 1960:887, 888). S6 handhaaf Barth 'n metode in sy etiek wat die eer van God bo alles stel.

\section{ENKELE KRTTIESE OPMERKINGS}

Kuitert (1974:66) merk tereg op dat nêrens die Skrifberoep in die etiek so problematies geword het, as wanneer dit gaan om die vraag wat die mens moet doen nie. Die problematiek word verdiep deur die 'hoe'-vraag van die metode wat gebruik moet word met betrekking tot die Skrifberoep. Hierby word ook die gedagte gevoeg dat 'n moontlike uitweg wat gevind kan word as antwoord op die 'hoe'- en die 'wat'vraag, nie bloot net ' $n$ kompilasie sal wees van pluspunte van argumente wat uit verskillende agtergronde geneem is nie. Die insigte van twee uiteenlopende teologiese denkmodelle kan nie op 'n simplistiese wyse met mekaar versoen word nie (Van Huyssteen 1983:307). Met hierdie problematiek in gedagte word die induktiewe en deduktiewe metodes kortliks onderwerp aan kritiek en daarna word ' $n$ alternatiewe metode voorgestel waarna 'n teologiese fundering hiervoor gegee word. 
Wat die induktiewe metode betref, behoort 'n onderskeid gemaak te word tussen die situasie-etiek en etiese teologie aan die een kant en die kontekstuele teologie aan die ander kant. Die situasie-etiek en die etiese teologie maak erns met die situasie, sonder dat die mens normatief word. In sy kritiek teen die etiese teologie het Bavinck die opmerking gemaak dat dit nie die bedoeling van die ervaringsteologie is om die waarheid van die geloof uit die mens af te lei nie (Berkouwer 1974: 211). Dit gebeur egter wel by die kontekstuele teologie. Die mens word die kenbron van norme. Die mens word die openbaring van God. Dié aspek van die kontekstuele teologie het ernstige gevolge vir die samelewing. Tereg merk Norman (1983:199) op: 'It may be a recipe for perpetual tyranny.' Wie meen dat hy God is, sal ook goddelike beheer oor ander wil hè.

Die deduktiewe metode $k$ an op geen wyse versoen word met die induktiewe metode van die kontekstuele teologie nie, al probeer Boesak om kontekstuele teologie as Gereformeerd te omskryf (Boesak 1984:102). Die beweging van die mens na God kan nie identies wees met die beweging van God na die mens nie. Die deduktiewe metode beklemtoon God se handeling met die wêreld en met die mens as ' $n$ onomkeerbare gegewenheid. Alhoewel dit ten volle aanvaar word, is die gestalte wat deur die Ortodoksie hieraan gegee word nie aanvaarbaar nie. Die Skrifbeskouing wat gehandhaaf is, het meegebring dat geloof beskou is as die onvoorwaardelike aanvaarding van leerstellige waarhede, in plaas van 'n lewende verhouding met die lewende God self (Engelbrecht 1982:30, 31). Alhoewel die Ortodoksie 'n legitieme en edele motief gehad het, naamlik om die kosbare besit van die Christendom te verskans teen die oorheersing deur die humaniste, is die waarde van die mens voor God misken en word van die mens 'n sacrificium intellectus verwag. Die Reformatoriese teologie van Luther, Calvyn en Barth bevat metodologies noodsaaklike korreksies op die siening van die Ortodoksie.

\section{DIE SIMBIOTIESE METODE}

Simbiose is 'n term wat geleen word by die plante- en diereryk. Dit beskryf die saambestaan van verskillende organismes tot mekaar se voordeel. In die teologie wil hierdie term aandui dat 'n metode gevolg word wat die saambestaan van God en mens erken. Die uitgangspunt is dat God, mens en wêreld refleksief op mekaar betrekking het (Bonhoeffer 1955:179-184). Die teologiese onderbou hiervan maak dit duidelik wat die aard van hierdie wederkerige verhouding is:

- Die wonder van God se werk word erken. In die saambestaan van God en mens word ruimte gelaat vir die wonder van God. Dit is 'n aspek wat by die kontekstuele teologie totaal verlore geraak het. Die wonder van God behels 
die erkenning dat God 'loodreg van bo' ingryp in hierdie wêreld (Barth 1960: 586). God word nie verhorisontaliseer nie. Hy bly ten spyte van die wonder, sy skepping, onderhouding, die vleeswording en voleinding, steeds deus absconditus (Luther) sodat hy op paradoksale wyse dialekties tegelyk as die Gans Andere, God met ons is. Vir die etiek beteken dit, aan die een kant, dat die skepper nooit skepping mag word nie en dat die skepsel en skepping, aan die ander kant, nooit skepper mag word nie.

- Die sondige mens is afhanklik van God. Bogenoemde beskouing oor God raak ten nouste die beskouing oor die mens. Die mens in sy saambestaan voor God is 'n sondaar wat afhanklik van God is. As begenadigde sondaar is die mens ' $n$ instrument in die hand van God wat geroep is tot medewerking met sy verstand, wil en krag. Die samewerking en saambestaan van die mens voor God word gekenmerk deur die feit dat die mens bo alles selfkennis verkry in sy verhouding met God (Calvyn). Die wese van die mens word daarom nooit die kenbron van die etiese nie. Vir die etiek beteken dit dat die mens nie outonoom mag wees in die sin dat hyself die hoogste gesag word nie, maar eerder 'n mens moet wees wat op die Woord antwoord sal gee (vgl Barth).

- Die Skrif is die getuienis van die openbaring van God. Die Skrif is die kenbron van die etiese. Die Skrif word egter nie gesien as 'n wetboek wat op meganiese wyse geïnspireer is en voorskrifte gee wat direk op absolute wyse neerslag moet vind in die lewe van 'n mens nie. As getuienis van die openbaring van God vind 'n refleksiewe interaksie plaas tussen die Woord van God en die mens van vandag binne sy gegewe situasie (Luther). Die eksistensiële of konkrete aspek van die mens se lewe is 'n deelgenoot in die gesprek tussen God en mens. Dit vra 'n gelowige luister na die Woord, besinning, oorweging en besluitneming, sodat die Woord normatief, nie in sy destydse vorm nie, maar in eietydse vorm, sal spreek. Vir die etiek beteken dit dat die situasie al luisterend na die Woord van God in ag geneem moet word, sodat die Woord tot sy reg sal kom binne'n gegewe konteks. Kontekstualisering, in hierdie sin, word verstaan as die vertaling van die evangelie vir ' $n$ besondere situasie as 'n wisselwerking tussen teks en konteks (Engelbrecht 1989:380).

- 'n Pariteit bestaan tussen dogmatiek en etiek. Die simbiotiese metode veronderstel dat ' $n$ pariteit tussen dogmatiek en etiek gehandhaaf moet word. Die een hoef nie die ander te oorheers nie, want albei is gewortel in dieselfde geloof. Rothuizen (1973:83) verwoord hierdie pariteit deur dogmatiek te omskryf as die 'regtheid van geloof' en 'etiek as die egtheid van geloof. Op voetspoor hiervan kan volstaan word om dogmatiek te omskryf as die 'egtheid van geloof. 
Etiek kan eerder omskryf word as die 'opregtheid van geloof'. Hiermee word 'n poging aangewend om die regte verhouding aan te dui tussen geloof, aan die een kant, en die gesindheid en daad, aan die ander kant. Op hierdie wyse word erkenning gegee aan die taak van die Christelike etiek om mense te konfronteer met en te lei tot die geloofswaarheid binne sy leefwerklikheid (Thielicke 1981: $33,63,64)$.

Die voorgestelde simbiotiese metode grens hom af teen sowel 'n uitsluitlik induktiewe as 'n uitsluitlik deduktiewe metode in die etiek soos verteenwoordig deur die kontekstuele teologie en die Ortodoksie. Die voorstel is dat sowel die Skrif as die situasie in die metode van die Christelike etiek verreken behoort te word. Die keuse wat uitgeoefen word, is nie ' $n$ df...df nie, maar ' $n$ en...en - Skrif en situasie, God en mens.

Eerstens beteken dit prakties dat die Christelike etiek nie op 'n absolute wyse die Woord afdwingbaar kan maak so asof die norm, wat sy vorm betref, vir tyd en ewigheid voorskriftelik is nie. Tweedens beteken dit ook dat die Christelike etiek nie relativisties mag wees nie, so asof die mens outonoom is vir wie geen norme of waardes bestaan nie, behalwe dié wat hy self skep. Die simbiotiese metode wil die mens daarop attent maak dat hy nie anders as voor die oog van God (coram Deo) kan bestaan nie. Die mens kan homself alleen verstaan en uitleef in die lig van God se genadige handeling met hom in Jesus Christus. Daarom verkies ons om te praat van ' $n$ Christelike etiek.

Om hierdie rede is dit belangrik dat die evangelie nie lewensvreemd sal spreek nie, al het dit 'n lewensbevrydende boodskap vir die sondige mens. Die moderne mens moet besef dat die erkenning dat dit in die evangelie gaan om God en mens en dat die mens saam met God in hierdie wereld bestaan, bepalend is vir sy werklikheidsverstaan en -belewing. Die lewe van die mens is onlosmaaklik verbind aan die feit dat 'God met ons' is. Op grond van die simbiotiese metode word dit moontlik om die taak van die Christelike etiek nuut te formuleer: Die Christelike etiek wil die moderne mens verbind aan die lewende God sodat die mens met sy bestaansnood heil kan vind in 'n bondgenootskap met God. Met hierdie besinning is ietwat beweeg op ' $n$ terrein wat in die moraalteologie bekendstaan as 'stance', perspektief of horison. Dit dui op die mees fundamentele en logies eerste oorweging met betrekking tot die sistematisering van die etiek (Curran $\mathrm{j}$ :92). Dit spreek dus vanself dat die simbiotiese metode slegs ' $n$ vertrekpunt is en dat verdere besinning oor 'n etiese model, 'n paradigma en die praktiese gevolge daarvan noodwendig moet volg. 


\section{Literatuurverwysings}

Assmann, H 1975. Practical theology of liberation. London: Search Press.

Barth, K 1960. Kirchliche Dogmatik. Vol I/2. Zürich: Evangelischer Verlag.

..- 1964. Kirchliche Dogmatik. Vol 1/1. Zürich: Evangelischer Verlag.

..- 1969. Kirchliche Dogmatik. Vol III/4. Zürich: Evangelischer Verlag.

Berkouwer, G C 1974. Een halve eeuw theologie. Kampen: Kok.

Boesak, A 1984. Black and reformed. Johannesburg: Skotaville Publishers.

Bonhoeffer, D 1955. Ethics. London: SCM Press.

Buro vir Suidelike Afrika 1985. TFP Nuusbrief no 19.

Calvyn, J 1956a. Institutie I. Vert deur A Sizoo. Delft: WDM.

-.- 1956b. Institutie II. Vert deur A Sizoo. Delft: WDM.

... 1956c. Institutie III. Vert deur A Sizoo. Delft: WDM.

Cauthen, K 1986. Systematic theology: A modern protestant approach. Lewiston: Edwin Mellen.

Cone, J H 1975. God of the oppressed. New York: Seabury Press.

Curran, C E s j. Method in moral theology, in Hamel, R P \& Himes, K R (eds), Introduction to Christian ethics, 90-105. New York: Paulist Press.

De la Saussaye, C 1922. Het Christelijk leven. Haarlem: De Erven F Bohn.

Dussel, E 1988. Ethics and community: Liberation and theology. Vol 3. Great Britian: Burns \& Oats.

Ebeling, G 1970. Luther: An introduction to his thought. Philadelphia: Fortress.

Encyclopedia of Religion 1987. s v Calvin.

Engelbrecht, B J 1978. Teologie in die kerk. Pretoria: HAUM.

-.. 1979. Temas rondom die Reformasie. Pretoria: HAUM.

-.- 1982. Versamelde opstelle, deel 3. Pretoria: Universiteit van Pretoria (Teologie Afd A).

Engelbrecht, E 1989. Kontekstualisering as hermeneutiese vraagstuk. HTS 45/2, 370-386.

Fletscher, J 1966. Situation ethics. London: SCM Press.

Frey, C 1989. Die Ethik des Protestanismus. Gütersloh: Verlaghaus.

Gutierrez, G 1974. A theology of liberation. London: SCM Press.

Hebblethwaite, B 1982. Christian ethics in the modem age. Philadelphia: Westminster Press.

Institute for Contextual Theology, 1987. The Kairos Document. Braamfontein: Skotaville Publishers.

Kuitert, H M 1974. Anders gezegd. Kampen: Kok.

Lohse, B 1974. Epochen der Dogmengeschichte. Berlin: Kreuz Verlag. 
Luther, M 1502. Christian liberty, in The Harvard Classics. 1981. Danbury: Grolier Enterprice Corp.

Mkhatshwa, S 1990. The role of contextual theology in a changing South Africa. Journal of Theology for Southern Africa 72, 3-8.

Mogoba, S 1975. The church in a future South Africa. Voordrag gelewer by die Nasionale Konferensie van die South African Council of Churches. Johannesburg.

Nolan, A R B \& Broderick, R 1987. Theology of liberation for Southern Africa. Hilton: Order of Preachers.

Norman, R 1983. The moral philosophers: An Introduction to ethics. Oxford: Clarendon.

Pont, A D 1984. Luther die hervormer, in Martin Luther-1483-1546. Pretoria: KITAL.

Rothuizen, G Th 1973. Wat is ethiek? Kampen: Kok.

Schultze, C F 1984. Luther se leer van die regverdiging deur die geloof alleen, in Martin Luther-1483-1546. Pretoria: KITAL.

Thielicke, H 1973. Theologische Ethik II/1. Tübingen: Mohr.

Van Huyssteen, W 1983. Thomas Kuhn en die vraag na die herkoms van ons teologiese denkmodelle. NGTT 24/3, 296-311.

Van Wyk, J H 1986. Gesindheid en gestalte. Pretoria: NG Kerkboekhandel.

Weber, O 1964. Grundlagen der Dogmatik. Neukirchen-Vluyn: Neukirchen Verlag. 